\title{
ETHNO-CULTURAL ASPECT OF PERSONALITY DEVELOPMENT IN THE EDUCATIONAL SYSTEM
}

\author{
(C) Vadim N. Goncharov, Olga Yu. Kolosova, Aleksandr A. Volkov
}

\author{
North-Caucasus Federal University \\ Krasnodar University of the Ministry of Internal Affairs of the Russian Federation, \\ Stavropol, Russian Federation \\ science-almanac@mail.ru
}

In a multi-ethnic state, the general principles for solving ethnocultural problems are often given by a political formula expressing the general national-state idea, including the principles of ethnic integration. An educational institution is one of the sociocultural mechanisms for implementing a specific national-state idea. Cultural differences, especially in customs and religion, were perceived more or less tolerantly in many parts of the world. However, in such an important area of culture as education, tolerance is manifested much less frequently. The most receptive cultures responded to the globalization of the economy and industry of Western culture with measures aimed at finding and maintaining ethnocultural identities. The self-assertion of ethnoculture becomes a force that makes it possible to withstand the crisis of identity generated by globalization. As a result of ethnocultural self-affirmation, new modern forms of expression of identity arise. The processes taking place on a global scale are characterized by the desire of peoples to maintain their identity, emphasize the uniqueness of their culture and psychological makeup, and millions of people to realize their belonging to a particular ethnic group. A person feels the non-stability of the world. He seeks protection, support and self-confidence in the enduring, eternal, stable values of his ancestors, seeks to preserve his identity, unique culture. Interest in their roots in individuals and entire nations is manifested in a variety of forms: from the revival of ancient customs and rituals, folklorization of culture, to the desire to create and restore their national statehood. Therefore, it is intergenerational stable communities, primarily ethnic groups, which acquire great significance in the life of the modern man. Ethnocultural revival is considered as one of the main features of human development in the 21st century. The main channel for the reproduction of culture in society is education, one of the broadest spheres of human activity, a specific structural element of ethnic culture that fulfills the function of continuity of generations.

Key words: personality, public consciousness, education, education, pedagogical system, civilization, ethnic culture, ethnic community, cultural self-identification.

\section{[В.Н. Гончаров, О.Ю. Колосова, А.А. Волков Этнокультурный аспект развития личности в образо- вательном процессе]}

В полиэтническом государстве общие принципы решения этнокультурных проблем часто задаются политической формулой, выражающей общую национально-государственную идею, включая и принципы этнической интеграции. Образовательное учреждение выступает одним из социокультурных механизмов реализации конкретной национально-государственной идеи. Культурные различия, особенно в сфере обычаев и религии, во многих районах мира воспринимались более или менее терпимо. Однако в такой важной области культуры, как образование, терпимость проявляется значительно реже. На глобализацию экономики и индустрии западной культуры наиболее восприимчивые культуры отреагировали мерами, направленными на поиск и сохранение этнокультурной самобытности. Самоутверждение этнокультур становится силой, дающей возможность выдержать кризис самобытности, порожденный глобализацией. В результате этнокультурного самоутверждения возникают новые современные фрормы выражения самобытности. Процессы, проходящие в мировом масштабе, характеризуются стремлением народов сохранить свою самобытность, подчеркнуть уникальность своей культуры и психологического склада, осознанием миллионами людей своей принадлежности к определенному этносу. Человек ощущает нестабильность окружающего мира. Он ищет защиту, поддержку и уверенность в себе в непреходящих, вечных, стабильных ценностях своих предков, стремится сохранить свою самобытность, уникальную культуру. Интерес к своим корням у отдельных людей и целых народов проявляется в самых разных фрормах: от возрождения старинных обычаев и обрядов, фрольклоризации культуры, до стремления создать и восстановить свою национальную государственность. Поэтому именно межпоколенные стабильные общности, прежде всего этносы, приобретают существенное значение в жизни современного человека. Этнокультурное возрождение рассматривается как одна из основных черт развития человечества в XXI веке. Основным каналом воспроизводства культуры в обществе является образование, од- 
на из обширнейших сфер человеческой деятельности, специфический структурный элемент этнокультуры, выполняющий функцию преемственности поколений.

Ключевые слова: личность, общественное сознание, воспитание, образование, педагогическая система, цивилизация, этническая культура, этническая общность, культурная самоидентификация.

Vadim N. Goncharov - Ph.D. (Advanced Doctorate) in Philosophy, Associate Professor, North Caucasus Federal University, Stavropol, Russian Federation.

Olga Yu. Kolosova - Ph.D. (Advanced Doctorate) in Philosophy, Associate Professor, Stavropol Branch Krasnodar University of the Ministry of Internal Affairs of the Russian Federation, Stavropol, Russian Federation.

Aleksandr A. Volkov - Ph.D. (Advanced Doctorate) in Psychology, Professor, North Caucasus Federal University, Stavropol, Russian Federation.

Гончаров Вадим Николаевич - доктор философрских наук, доцент, Северо-Кавказский фредеральный университет, г. Ставрополь, Российская Федерация.

Колосова Ольга Юрьевна - доктор фрилософрских наук, доцент, Краснодарский университет Министерства внутренних дел Российской Федерации, г. Ставрополь, Российская Федерация.

Волков Александр Александрович - доктор психологических наук, профессор, Северо-Кавказский фредеральный университет, е. Ставрополь, Российская Федерация.

The key task of the educational process today is to assist students in the development of the cultural heritage created by humanity. Human nature is transforming and getting better thanks to culture. Cultural self-education, self-improvement have a beneficial effect on the processes of human mental activity. Thanks to these classes, a person becomes more capable of realizing the complex, subtle tasks of his life. The process of cultural creation, continuous, repeated by generations, leads to internal changes in the structure of the brain, which subsequently become fixed and turn into hereditary. Only in that case, the educational process will be effective when the basis will be laid on the direction of human formation, the mechanisms of assimilation of culture, based on science, involving certain objects of scientific research. Moreover, "the requirements for the information support of objects ... change in the process of scientific research" [5, pp. 123-128].

A key feature of the educational process is its characterization as an intentional or deliberate process. This trait helps a person to become a part of the integral being of culture, helps to comprehend and realize to a single individual the generic and species meaning of life. It began to exist when a need appeared, and was intentionally created by man. Education, as a purposeful process organized by society, will take place more successfully if factors influencing a person are more fully taken into account, in particular, the objective living conditions of a person. Thanks to a variety of activities regarding various elements of both material and spiritual culture, the younger generation, under the leadership of the older generation, comprehends its wealth and develops specific abilities embodied and crystallized in these components of culture.

The process of education is a very significant process both for society as a whole and for the individual in particular. Education is the most technological and moving part of culture. This process also creates the opportunity to enter the world of culture globally, and, as a result, both social consciousness and individual consciousness are formed. True education is not limited to simply transmitting the finished cultural product to the younger generation, the key component and its peculiarity is determining the direction of movement for the development of culture and developing its own new cultural content.

Pedagogy interprets culture as a complex of material and spiritual activities developed by humankind, which becomes its property and is assimilated by a person. In this connection, the time has come to solve such a complex task as searching, in the whole variety of activities, for elements common to all types that are to be assimilated, regardless of the nature of 
future specific human affairs. When assimilating these elements, the preservation and further development of culture is ensured. However, for the fact that culture has been assimilated, it is worth noting the significance of social experience, that is, the importance of the form of expression of culture in knowledge about this culture, in the ways of activity that are the legacy of the older generation. The key function of education is expressed in the translation of ethnocultural experience.

The educational process is the main social activity, the key institution of society, which was created for the processes of socialization and personality formation, the transmission to the new generation of existing experience, knowledge, axiological attitudes, norms, that is, everything that can determine the system of views and ideas about the world, about a person's place in the world and, as a result, about individual and collective behavior of people. Education is considered as a course and consequence of a goal-setting, pedagogically formed and methodically organized process of socialization of a person's personality, which is carried out in the interests of both the person himself and in the interests of the society of which this person is a part. A person is actively socialized through the targeted influence of the educational process, which consists of the means developed by culture for the holistic development of a person's personality, for the formation of a person as a person in close connection with the culture of society.

The education process is highly dependent on ethnic culture, ethical values, the level of spirituality, and not only on the trends of socio-economic development of society. The educational process responds to the natural environment of the ethnic group, it also includes the foundations of the ethnic group in all areas of activity.

Each pedagogical system has an ethnocultural nature, due to its reproduction in younger generations. In the process of obtaining education in society, the ascent from the individual to the ethnosociocultural is practically carried out, a movement towards universal skills and knowledge is carried out, a cultured person is able to do everything that others do. Education, as a fact of collective consciousness, is involved in maintaining and reproducing the ethnocultural structure of this social mechanism.

The process of education as a goal and result highlights, on the one hand, the ontogenesis of human self-awareness, its independence, the ability to be creative, original, autonomous person, and on the other hand, the process of successful integration into communities, whether it is a family, class, estate or community, as well as familiarization with generally accepted rules and norms of behavior, inclusion in the system of social values, suggesting "the need to consider ... dispositions of social structures" [1, p. 168-177]. Their awareness and implementation depend on ethnic characteristics and are fixed in the basic educational traditions inherent in the ethnic group, which include established ethnic stereotypes. Since the ethnic stereotype can be formed both in everyday consciousness and in theoretical consciousness, the design of the ethnic stereotype rests with the education system, which controls, organizes the cognitive and emotional aspects of the acquisition of ethnic stereotypes. As a result, the identification of symmetrical features of the process as a whole will appear as a requirement. In addition, there is a need to disclose the pedagogical laws of the formation of ethnic identity. The education process should be aimed at discovering and identifying the best qualities of a person, ethnic self-awareness for the rapprochement of cultures and peoples.

In matters of solving the problems of the formation of culture, the educational tasks of society, the decisive role belongs to the educational system and the organized and focused ethnocultural pedagogical process implemented within it, which implements the main functions of education - training, upbringing, development. The education system is an integral element of the structure of society, ensuring the normal functioning of it, therefore, the goals and objectives of education should meet the goals and objectives of the whole society, determine "the quality of a person and the resulting ability of social agents to purposefully inter- 
act with the environment" [10 , pp. 282-284], given the context of the "formation of a new social reality" [11, pp. 64-68], as well as the complex interaction of various types of social communication [2].

The educational system is a focused, coordinated public institute of an ethnos defined by "...forms of spiritual and practical development of the world" [6, p. 9-12]. This is an original subject of mastering an ethnocultural experience. Ontogenesis of the educational system is associated with the basic laws of the development of the ethnic group

Although the education system is undergoing some crisis, its role in the life of various peoples and states is gaining momentum. This process, characterized as a paradigm crisis leading to a change in the educational model, its ideal: from an educated person to a person of culture. The new paradigm is associated with the deepening and development of ethnocultural principles. P. Noikov named the reasons that led to self-determination in world civilization, the combination of multifunctional ideals with ethnocultural characteristics, including the need for the young generation to develop a sense of belonging with their people, a desire to work for its prosperity and happiness, and pedagogically influence on the thinking of an ethnic group, to make the most of life's experience of an ethnocultural nature.

Proponents of the humanistic approach see the danger in the lag in the whole spiritual culture of mankind from the material, in turning education into a utilitarian teaching of professional knowledge and skills. Education loses its humanistic meaning.

Humanism is love for humankind, humanism, it is equivalent to considering a person as an individual who, by birth, has parity with other people, regardless of nationality and faith, natural and social rights to be free, to develop their abilities and talents, moral qualities, to work in the name of affirming human benefits, serve the world, people's friendship, enter the system of public relations with a good disposition, respect for the dignity of each individual, the desire to be useful to society. I. Kant gave a precise definition of the essence of humanism i.e. humanity, companionship, love for humankind", its main components are a sense of good, a sympathetic attitude towards people around and the opportunity to communicate with them so that humanity turns into a partnership of mutually cooperating, understanding people.

Humanism is expressed, first of all, for the purposes of education, which are not limited only to the formation of theoretical and methodological equipment of thinking and practical activity, the main thing is what this thinking and practical abilities of a person will be oriented to. Education in a humanistic sense is not just learning. The task of training is simpler than the problem of human education in its entirety. If education is humanistic, then this is not just training, but above all, the formation of a personality in all the multidimensional completeness of the intellectual and ethnocultural development of a person.

In the most generalized form, the humanization of education is the creation of the most favorable conditions for the disclosure and development of the abilities and gifts of the child, for his self-determination. This is overcoming ageless education, taking into account the psychophysiological identity, the characteristics of the social and ethnocultural context of a child's life, the complexity and ambiguity of his inner world. Humanization is a key moment of new pedagogical thinking. It requires a review, re-evaluation of all components of the pedagogical process in the light of their human-forming function. It radically changes the essence and nature of this process, putting it in the center of the child. The main meaning of the pedagogical process is the development of the student. The measure of this development acts as a measure of the quality of work of the teacher, school, and the entire educational system.

Humanizing education means making it personally significant for every person. In the content of education, it is necessary to include the human dimension, the personal principle, that is, subjective scientific knowledge. Education is aimed at the formation of personality functions - the choice of an activity strategy, responsibility for decisions made, selfdetermination, that is, it is intended to promote the growth of a person as a person. The hu- 
manization of education inevitably entails an increase in the focus of the educational process on satisfying ethnocultural needs, ensuring the preservation and reproduction of ethnocultural values and traditions. The interest in the phenomenon of ethnocultural demands and educational needs is associated with the general process of humanization of social consciousness and, as a consequence, with an increase in the proportion of universal elements in the content of education.

Humanistic traditions, going back centuries, originate in folk pedagogy, an integral part of culture, a phenomenon that reflects the pedagogical traditions of the people and their culture, which determines the formation of valuable orientations among the young generation. Educational traditions have a powerful humanistic potential embodied in the spiritual and cultural heritage of the people, in the ideals, means and methods of folk pedagogy.

The roots of folk education lie deep in antiquity. Education, as one of the main areas of folk pedagogy, has been tested and developed over many generations. Therefore, G.N. Volkov notes that the truths of pedagogy are true and eternal, just like biblical ones. Violation of pedagogical truths can lead to disastrous consequences.

The basis of popular, national education, that is, the basis of traditional pedagogy, the traditional culture of education is the foundation of modern education.

At the same time, it is a kind and core, a spiritual core of humanistic pedagogy. The pedagogical culture of each nation is different in its uniqueness, as it reflects the peculiarities of the ethnos being. Orientation to folk traditions, culture realizes the essential needs of the individual in the present and future on the basis of the development of spiritual values of the past and the present. The orientation process has three interpenetrating phases: the appropriation by a person of the values of folk pedagogy; personality transformation based on the assigned values of ethnopedagogy; self-design, or the forecast of personality for the future.

For a national revival, an appeal to national pedagogical traditions is necessary. Ethnopedagogy is based on seven fundamental axioms-criteria: naturalness, the early start of education, its hierarchy, nature conformity, the completeness of the pedagogical cycle i.e. a three-generation family, a comprehensive approach to education, an inventory of experience and ideas of folk pedagogy. These are the seven pillars on which the whole construction of public education rests.

The problem of generation gap and continuity is one of the most important for humankind, as well as the problem of the formation of a new generation culture, education and inclusion in the wealth of ethnic culture is a key one. The problem of correlation of the universal human mission of education common to all humankind and its ethnocultural function is associated with the transfer from generation to generation of a unique ethnocultural heritage and the preservation of ethnic identity. Categories of knowledge, the value of which does not depend on time, should become the property of every person.

Thanks to such features as continuity, variability and inertness, it is possible to transfer basic values in upbringing from one generation to another, taking into account the changing socio-political, socio-economic conditions, a positive perception of one's historical past, and finding the deepest meanings of social being through the comprehension of one's own national roots and the revival of the best folk traditions; also taking into account the religious aspects of social life, forming a religious consciousness, which "emphasizing the impact on the theological ideas of the philosopher" [7, pp. 29-31], notes "the influence of Orthodoxy on the formation and design of Russian culture" [12, pp. 39-44].

The development of the idea of continuity in public consciousness, reflecting the requirements for subsequent conscious activity [3, pp. 14-17], inevitably involves a process of reforms and innovative changes in the education system, aimed at reviving the historically established ethnoculturally oriented forms of education that not only implement the principle of variability, but also try to create their own model based on ethno-educational tradition. 
Such an approach involves the creation of an educational system in which students learn their own culture and language and at the same time, the content of education brings personality to the world cultural space. Consequently, the goals of the educational system are to obtain a complete secondary education, to introduce children of different ethnic groups to their national culture, language, history, and traditions.

Appeal to the pedagogical experience of the people, philosophical, ethnocultural heritage is an important natural condition for understanding the genesis of a person's worldview at the stages of development of his people's culture, ethnic culture, and world civilization. Ethnoculture implies a structure that forms a certain type of personality [9, pp. 15-18]. It creates favorable conditions for the humanization of education, for the moral improvement of personality, as well as for the preservation, enrichment and development of ethnic culture [8].

Ethnoculture is an integrative means uniting education and upbringing. Education as the most important social mechanism for maintaining the identity of a society plays a decisive role in recognizing the necessity and beneficence of multiple human differences. Education cannot be considered outside the general mental movement of the people. In modern society, education becomes the main factor in the revival, preservation and development of ethnic culture and self-awareness.

The process of education is a complex of coordinated, pedagogically controlled processes of identifying a person with a culture; it is social adaptation and creative selfrealization of a person. As a result of this process, a person enters into culture, into the life of society, creative abilities and capabilities of a person develop. According to I.S. Kona, the axiologically fundamental image of a person and the goal, tasks and methods of the educational process firmly connected with it, inherently depend on the culture inherent in a person, which is the axis of the everyday psychology of the class, ethnic group, society as a whole, combining the specifics of axiological attitudes, expectations, and features of social education.

An implicit, or implied, or unexpressed theory of personality is one of the main value guidelines with which all forms of social actions will be related to one degree or another, especially the educational process of the younger generation. So, Ya.A. Komensky substantiated the universal process of educating all people, the formation of the young generation's ability to live in a human community, fulfilling the responsibilities that exist for each other, ability to respect other people, through a message about the community of all people, the whole society, its aspirations and needs.

The principles of cultural conformity determine the relationship between the process of education and culture as a kind of environment that grows and nourishes the individual. In addition, between the process of education and the process of development of a person as a person of culture.

This, in turn, means that the universal core of human principles and values should be the cultural core of the educational process, and the attitude to the educated person should be based on the perception of a holistic, free person who is capable of independently choosing value orientations in her development, capable of self-determination in society, capable of self-realization of the creative beginning of herself. The upbringing process in this case will not impose one or another system of values, but will only create certain conditions for their demarcation, for awareness and choice, it will stimulate this choice and further internal work of the educated person on his own actions and actions. The main purpose of the cultural-like educational process is to form different cultural environments, where the process of development of the educated takes place and he gets the social experience of the cultural-like behavior. In addition, in the framework of this process, assistance can be provided to a person brought up for cultural self-realization and self-identification of his abilities and talents. That is, it is an educational process that encourages the cultural self-development of the educated. This process is based on the idea of self-development of the educated as a creative person. 
E.V. Bondarevskaya speaks of a person of culture as a goal of modern education. A person of culture is called a free, humane (humanized), creative, spiritual person. The key property of a completed image of a person of culture stands out his ability to culturally identify himself, that is, to realize his belonging to a particular culture, the transition to its values, the choice and implementation of lifestyle and behavior in accordance with this particular culture. The education process is able to preserve culture if it takes on a mission to educate a person of culture on itself, and if through man himself the mission of preserving, restoring and improving culture as a kind of environment, universal manifestation, ensuring "... the upbringing of a positive attitude towards cultural differences" [ 4, pp. 7-10], promotes the dialogue of cultures in the development of modern civilization.

\section{Лumepamypa}

1. Бакланова О.А., Бакланов И.С. Современная российская социальность в контексте социального конструкционизма // Вопросы социальной теории. 2015. Т. 7. № 1-2. C. 168-177.

2. Власова В.Н. Сущность интегративности как предмета и метода проектирования образовательного пространства // Гуманитарные и социально-экономические науки. 2006. № 3 (22). С. 150-153.

3. Говердовская E.В., Болховской А.Л. Информационная парадигма современного общества: социально-фрилософрский и педагогический обзор концепций // Гуманитарные, социально-экономические и общественные науки. 2013. № 7-1. С. 14-17.

4. Говердовская E.B. Особенности проектирования образовательного пространства высшей школы в поликультурном регионе // Экономические и гуманитарные исследования регионов. 2014. № 4. С. 7-10.

5. Ерохин А.М. Научно-информационный аспект исследования социокультурного развития общества в области культуры и искусства // Экономические и гуманитарные исследования регионов. 2015. № 2. С. 123-128.

6. Ерохин А.М. Религия и искусство в системе культуры // European Social Science Journal. 2014. № 7-2 (46). C. 9-12.

7. Камалова О.Н. «Созерцание» в фрилософрско-культурологических построениях И. Ильина // Гуманитарные и социально-экономические науки. 2012. № 6. С. 29-31.

8. Карташев А.В., Склярова Е.К., Камалова О.Н. Олимпиады по истории медицины: опыт организации и особенности проведения // Гуманитарные и социальноэкономические науки. 2017. № 1 (92). С.151-156.

9. Лобейко Ю.А. Социально-педагогический аспект активности личности в системе общественного развития // Экономические и гуманитарные исследования регионов. 2015. № 1. С. 15-18.

10.Лобейко Ю.А. Социальная активность личности в обществе: социальнопедагогические аспекты формирования // European Social Science Journal. 2014. №7-2(46). C. 282-284.

11. Лукьянов Г.И. Трансформационные процессы в современном российском обществе как отражение динамики новой социальной реальности // Экономические и гуманитарные исследования регионов. 2017. №4. С. 64-68.

12. Матяш Т.П., Несмеянов Е.Е. Православный тип культуры: идея и реальность // Гуманитарные и социально-экономические науки. 2015. № 3 (82). С. 39-44.

13. Nesmeyanov E.E., Olenich T.S., Plotnikov S.A. "Youth and Orthodox" within the context of traditional culture values formation (on the base of social research "Attitude of Rostov Region youth to Russian Orthodox Church and the believers in the context of the support of traditional culture values") // Научный альманах стран Причерноморья. 2016. №1 (5). 


\section{References}

1. Baklanova O.A. Baklanov I.S. Sovremennaya rossiyskaya sotsialnost v kontekste sotsialnogo konstruktsionizma. Voprosy sotsialnoy teorii. [Modern Russian sociality in the context of social constructionism. Questions of social theory]. 2015. V. 7. No. 1-2. pp. 168-177 (In Russian).

2. Vlasova V.N. Sushchnost integrativnosti kak predmeta i metoda proyektirovaniya obrazovatelnogo prostranstva. Gumanitarnyye i sotsialno-ekonomicheskiye nauki. [The essence of integrativity as an object and method of designing educational space. Humanitarian and socio-economic sciences]. 2006. No. 3 (22). pp. 150-153 (In Russian).

3. Goverdovskaya E.V., Bolkhovskiy A.L. Informatsionnaya paradigma sovremennogo obshchestva: sotsialno-filosofskiy i pedagogicheskiy obzor kontseptsiy. Gumanitarnyye, sotsialno-ekonomicheskiye i obshchestvennyye nauki. [The information paradigm of modern society: a socio-philosophical and pedagogical review of concepts. Humanities, socio-economic and social sciences]. 2013. No. 7-1. pp. 14-17 (In Russian).

4. Goverdovskaya E. V. Osobennosti proyektirovaniya obrazovatelnogo prostranstva vysshey shkoly $v$ polikulturnom regione. Ekonomicheskiye i gumanitarnyye issledovaniya regionov. [Features of designing the educational space of higher education in a multicultural region. Economic and humanitarian studies of the regions]. 2014. No. 4. pp. 7-10 (In Russian).

5. Erokhin A.M. Nauchno-informatsionnyy aspekt issledovaniya sotsiokulturnogo razvitiya obshchestva $v$ oblasti kultury $\mathrm{i}$ iskusstva. Ekonomicheskiye i gumanitarnyye issledovaniya regionov. [The scientific and informational aspect of the study of socio-cultural development of society in the field of culture and art. Economic and humanitarian studies of the regions]. 2015. No. 2. pp. 123-128 (In Russian).

6. Erokhin A.M. Religiya i iskusstvo v sisteme kultury. [Religion and art in the cultural system]. European Social Science Journal. 2014. No. 7-2 (46). pp. 9-12 (In Russian).

7. Kamalova O.N. «Sozertsaniye» v filosofsko-kulturologicheskikh postroyeniyakh I. Ilina. Gumanitarnyye i sotsialno-ekonomicheskiye nauki. ["Contemplation" in the philosophical and cultural studies of I. Ilyin. Humanitarian and socio-economic sciences]. 2012. No. 6. pp. 29-31 (In Russian).

8. Kartashev A.V., Sklyarova E.K., Kamalova O.N. Olimpiady po istorii meditsiny: opyt organizatsii i osobennosti provedeniya. Gumanitarnyye i sotsialno-ekonomicheskiye nauki. [Olympiads on the history of medicine: the experience of organization and the features of the conduct. Humanitarian and socio-economic sciences]. 2017. No. 1 (92). pp. 151-156 (In Russian).

9. Lobeiko Yu.A. Sotsialno-pedagogicheskiy aspekt aktivnosti lichnosti $v$ sisteme obshchestvennogo razvitiya. Ekonomicheskiye i gumanitarnyye issledovaniya regionov. [Socio-pedagogical aspect of personality activity in the system of social development. Economic and humanitarian studies of regions]. 2015. No. 1. pp. 15-18 (In Russian).

10. Lobeiko Yu.A. Sotsialnaya aktivnost lichnosti $v$ obshchestve: sotsialnopedagogicheskiye aspekty formirovaniya. [The social activity of the individual in socie- 
ty: socio-pedagogical aspects of formation]. European Social Science Journal. 2014. No. 7-2 (46). pp. 282-284 (In Russian).

11. Lukyanov G.I. Transformatsionnyye protsessy $v$ sovremennom rossiyskom obshchestve kak otrazheniye dinamiki novoy sotsialnoy realnosti. Ekonomicheskiye i gumanitarnyye issledovaniya regionov. [Transformational processes in modern Russian society as a reflection of the dynamics of a new social reality. Economic and humanitarian studies of regions]. 2017. No. 4. pp. 64-68. (In Russian).

12. Matyash T.P., Nesmeyanov E.E. Pravoslavnyy tip kultury: ideya i realnost. Gumanitarnyye i sotsialno-ekonomicheskiye nauki. [Orthodox type of culture: idea and reality. Humanitarian and socio-economic sciences]. 2015. No. 3 (82). pp. 39-44. (In Russian).

13. Nesmeyanov E.E., Olenich T.S., Plotnikov S.A. "Youth and Orthodox" within the context of traditional culture values formation (on the base of social research "Attitude of Rostov Region youth to Russian Orthodox Church and the believers in the context of the support of traditional culture values"). Science almanac of Black Sea Region Countries. 2016. No.1 (5). 